\title{
MIKROSIMULASI KINERJA SIMPANG BERSINYAL DENGAN MENGGUNAKAN SOFTWARE SURROGATE SAFETY ASSESSMENT MODEL (SSAM) DI KOTA MALANG (Studi Kasus: Simpang Terusan Sulfat)
}

\author{
Pipit Rusmandani $^{1^{*}}$, Enrico Pria Anggana ${ }^{2}$, Agus Sasmito ${ }^{3}$ \\ 1Dosen / Manajemen Keselamatan Transportasi Jalan / Politeknik Keselamatan \\ Transportasi Jalan \\ 2Mahasiswa / Manajemen Keselamatan Transportasi Jalan / Politeknik \\ Keselamatan Transportasi Jalan \\ 3 Dosen / Manajemen Keselamatan Transportasi Jalan / Politeknik Keselamatan \\ Transportasi Jalan \\ *Korespondensi: pipit@pktj.ac.id
}

\begin{abstract}
Safety, speed, and capacity should be taken into account for designing intersection (AASHTO, 2001). Therefore, it is necessary to know the conflicts at the intersection. This experimental research aims (1) to find out the performance of Malang Sulfate Canal intersection, (2) to know the conflicts in it, and (3) to find the best recommendation. MKJI, PTV Vissim 10, and Surrogate Safety Assessment (SSAM) were used for data analysis. The result shows that the delay value at the peak hour was 54.4 seconds with an E service level category. The conflicts at the highest peak hours were 2782 conflicts $(2035$ crossing conflicts and 747 lanechange conflicts). At the end, widening the road reduced the number of traffic conflict by $26 \%$ and the delay value by $2 \%$.
\end{abstract}

Keywords: Intersection, conflict, safety

\section{PENDAHULUAN}

Pada persimpangan, tiap-tiap pendekat memiliki karakteristik kecepatan yang berbeda sebab terdapat perbedaan geometri jalan dan jumlah pergerakan yang ada. Kecepatan didefinisikan dengan jarak dibagi waktu tempuh, Kecepatan menjadi ukuran utama kinerja ruas jalan selain VCR (Volume Capacity Ratio) atau DS (Degree of Saturation). Pengaturan waktu pada simpang bersinyal sering kita jumpai kurang sesuai dengan kondisi lalu lintas yang ada, pengaturan fase dan waktu siklus yang kurang tepat menambah permasalahan yang ada pada simpang seperti waktu tundaan yang semakin lama serta terjadinya konflik lalu lintas sebagai indikator keselamatan. Keberhasilan dari pengaturan ini dengan Alat Pemberi Isyarat
Lalu Lintas (APILL) ditentukan dengan berkurangnya penundaan waktu untuk melalui persimpangan (waktu antre minimal) dan berkurangnya angka kecelakaan pada persimpangan yang bersangkutan. Konflik lalu lintas bisa terjadi karena pengaturan fase yang kurang sesuai dengan kondisi simpang yang ada sehingga antara kendaraan bisa saling bersinggungan, bisa seperti jenis konflik crossing, merging, diverging maupun rear end [1][2].

Simpang Terusan Sulfat merupakan simpang berukuran kecil dengan pengaturan waktu bersinyal 2 fase yang pada jam keberangkatan atau kepulangan kantor memiliki volume lalu lintas yang tinggi sehingga banyak kendaraan mengalami tundaan perjalanan. Seperti pada penelitian yang di 
lakukan oleh Pipit Candra Windarto [3], pada penelitiannya melakukan analisis kondisi eksisting dengan menggunakan pedoman MKJI selanjutnya pada usulan penanganan di lakukan simulasi menggunakan VISSIM. Pemodelan simpang bersinyal Terusan Sulfat menggunakan software VISSIM 10. VISSIM 10 adalah perangkat lunak aliran mikroskopis untuk pemodelan lalu lintas, simulasi dalam bentuk 2D dan 3D. Dalam upaya peningkatan keselamatan, simpang ini menggunakan pengaturan 2 fase dengan volume lalu lintas yang cenderung tinggi konflik lalu lintas pada simpang ini akan banyak terjadi karena kendaraan berjalan dengan berlawanan arah. Seperti pada penelitian Haitham AlRajie [4] membahas tentang model mikrosimulasi dengan SSAM dapat digunakan karena memiliki potensi untuk memprediksi konflik antara kendaraan dengan pesepeda di persimpangan bersinyal dengan cara membandingkan konflik antara model simulasi lalu lintas dengan konflik lalu lintas yang diamati secara langsung.

Penelitian ini merupakan bentuk upaya peningkatan keselamatan pada simpang Terusan Sulfat di Kota Malang dengan cara penanganan konflik lalu lintas. Penelitian ini bertujuan untuk memberikan penanganan simpang yang dapat menurunkan jumlah konflik lalu lintas dan diharapkan peningkatan pelayanan pada simpang bersinyal tersebut dapat memberikan kenyamanan dan keamanan pengguna jalan di simpang bersinyal Terusan Sulfat.

\section{TINJAUAN PUSTAKA}

Mikrosimulasi merupakan salah satu kategori dari model simulasi. Menurut Hormansyah, Sugiarto, dan Amalia (2017) mikrosimulasi adalah "simulasi pergerakan kendaraan secara individu dalam pergerakan arus lalu lintas". Pendekatan secara mikrosimulasi mengkaji beberapa parameter penting yang sangat mempengaruhi terhadap respons terhadap kendaraan itu sendiri dalam berlalu lintas di jalan raya. Adapun parameter yang dapat mempengaruhi adalah spacing, headway, lane occupancy, dan gap (clearance) [5].

\subsection{Konflik Lalu Lintas}

Konflik lalu lintas menurut Al-Rajie didefinisikan sebagai situasi yang dapat diamati di mana dua pengguna jalan atau lebih mendekati satu sama lain pada ruang dan waktu yang sama yang memiliki risiko terjadinya tabrakan jika gerakan mereka tetap tidak berubah. Konflik lalu lintas juga merupakan salah satu indikator yang digunakan untuk mengevaluasi aspek keselamatan dalam sistem transportasi [4].

Sesuai dengan kondisi lalu lintasnya, di mana terdapat pertemuan jalan dengan arah pergerakan yang berbeda, simpang sebidang merupakan lokasi yang potensial untuk menjadi titik pusat konflik lalu lintas yang bertemu, penyebab kemacetan, akibat perubahan kapasitas, tempat terjadinya kecelakaan, konsentrasi para penyeberang jalan atau pedestrian. Masalah utama yang saling mengkait di persimpangan adalah :

a. Volume dan kapasitas, yang secaralangsung mempengaruhi hambatan

b. Desain geometrik, kebebasan pandangan dan jarak antar persimpangan

c. Kecelakaan dan keselamatan jalan,kecepatan, lampu jalan,pejalan kaki, parkir, akses dan pembangunan yang sifatnya umum.

Pada umumnya pengaturan lalu lintas dengan menggunakan sinyal digunakan untuk beberapa tujuan, yang antara lain adalah :

a. Menghindari terjadinya kemacetan pada simpang yang disebabkan oleh adanya konflik arus lalu lintas yang dapat dilakukan menjaga kapasitas yang tertentu selama kondisi lalu lintas puncak.

b. Memberi kesempatan kepada kendaraan lain dan atau pejalan kaki dari jalan simpang yang lebih kecil untuk memotong jalan utama.

c. Mengurangi terjadinya kecelakaan lalu lintas akibat pertemuan kendaraan yang berlawanan arah atau konflik.

\subsection{Vissim}

Menurut PTV-AG [6], VISSIM adalah perangkat lunak multimoda simulasi lalu lintas aliran mikroskopis. VISSIM dikembangkan oleh PTV (Planung Transportation Verkehr AG) di Karlsruhe, Jerman. VISSIM berasal dari Jerman yang mempunyai nama "Verkehr Städten Simulationsmodell" yang berarti model simulasi lalu lintas perkotaan. VISSIM diluncurkan pada tahun 1992 dan berkembang sangat baik hingga saat ini.

VISSIM menyediakan kemampuan animasi dengan perangkat tambahan besar dalam 3D. 
Simulasi jenis kendaraan (yaitu dari motor, mobil penumpang, truk, kereta api ringan dan kereta api berat). Selain itu, klip video dapat direkam dalam program, dengan kemampuan untuk secara dinamis mengubah pandangan dan perspektif. Elemen visual lainnya, seperti pohon, bangunan, fasilitas transit dan rambu lalu lintas, dapat dimasukkan ke dalam animasi 3D [6].

\subsection{Surrogate Safety Assessment Model (SSAM)}

Menurut AlRaji, Surrogate Safety Assessment Model ( SSAM ) merupakan suatu metode yang dikembangkan oleh Federal Highway Administration Research and Technology yang dilakukan dengan cara menggabungkan antara mikrosimulasi dan analisis konflik secara otomatis serta menganalisis frekuensi dan karakter dari tipe konflik antar kendaraan pada suatu arus lalu lintas yang digunakan untuk menilai keselamatan lalu lintas tanpa menunggu jumlah kecelakaan dan cedera benar-benar terjadi [4].

Software SSAM menurut FHWA (2008) dikembangkan untuk mengotomatisasi analisis konflik dengan langsung memproses dari data simulasi pergerakan kendaraan. Para peneliti menetapkan format data pergerakan kendaraan dengan standar terbuka yang dirancang untuk menyediakan lokasi dan dimensi setiap kendaraan kira-kira setiap sepersepuluh detik. Namun, format file pergerakan lalu lintas yang dapat dibaca oleh software SSAM saat ini baru didukung oleh empat model mikrosimulasi lalu lintas, yaitu VISSIM, AIMSUN, Paramics, dan TEXAS [7]. Pada program SSAM dapat mengetahui beberapa hasil dari output data VISSIM yaitu dengan format trj. Yang menunjukkan hasil sebagai berikut :

a. Jumlah total konflik

b. Jenis konflik yang terjadi yaitu : crossing, lane change dan rear end

c. Nilai TTC dan PET konflik lalu lintas

\section{METODOLOGI}

Penelitian ini terletak pada persimpangan bersinyal Terusan Sulfat, persimpangan ini memiliki fungsi jalan arteri sekunder II dan status jalan perkotaan, oleh sebab itu persimpangan ini banyak di lalui kendaraan karena merupakan akses dari daerah asal ke tujuan terutama pada perkantoran, pertokoan dan sekolah-sekolah. Data yang dikumpulkan dalam penelitian ini terdiri dari data primer dan sekunder. Pengumpulan data primer diperoleh dari survei pada lokasi yang terdiri dari data:

a. Data kondisi geometrik

b. Arus lalu lintas (survei pencacahan arus lalu lintas)

c. Kecepatan Kendaraan

d. Waktu pengaturan APILL

e. Konflik lalu lintas

sedangkan data sekunder diperoleh dari data BPS (2018) yaitu Kota Malang memiliki jumlah penduduk 895.387 jiwa serta luas wilayah $145.28 \mathrm{~km}^{2}$.

Pada tahap analisis ini, hasil data pengamatan dikumpulkan dan selanjutnya akan dilakukan proses perhitungan dengan menggunakan Manual Kapasitas Jalan Indonesia (MKJI) 1997 dan dibantu dengan aplikasi yang mendukung. Analisis data juga bisa diartikan sebagai kegiatan yang dilakukan untuk merubah data hasil dari sebuah penelitian menjadi informasi yang nantinya bisa dipergunakan untuk mengambil sebuah kesimpulan. Inventarisasi simpang di gambarkan pada tampak atas 2D dengan menggunakan software autocad 2017 yang bertujuan untuk menggambarkan kondisi geometri simpang dan perlengkapan jalan. Analisis simpang menggunakan Manual Kapasitas Jalan Indonesia (MKJI) untuk mengetahui tingkat pelayanan dan selanjutnya menggunakan VISSIM untuk simulasinya yang bertujuan mendapatkan ouput data untuk di input pada software SSAM guna mengetahui jumlah konflik yang terjadi.

\section{HASIL DAN PEMBAHASAN}

\subsection{Kinerja Simpang Terusan Sulfat}

a. Kondisi Geometrik simpang

Kondisi eksisting Simpang Terusan Sulfat dapat diperjelas dalam Gambar 1 berikut :



Gambar 1. Kondisi Eksisting Simpang TerusanSulfat 
Data hasil inventarisasi pada simpang terusan sulfat dilihat pada Tabel 1 berikut :

Tabel 1. Data Inventarisasi

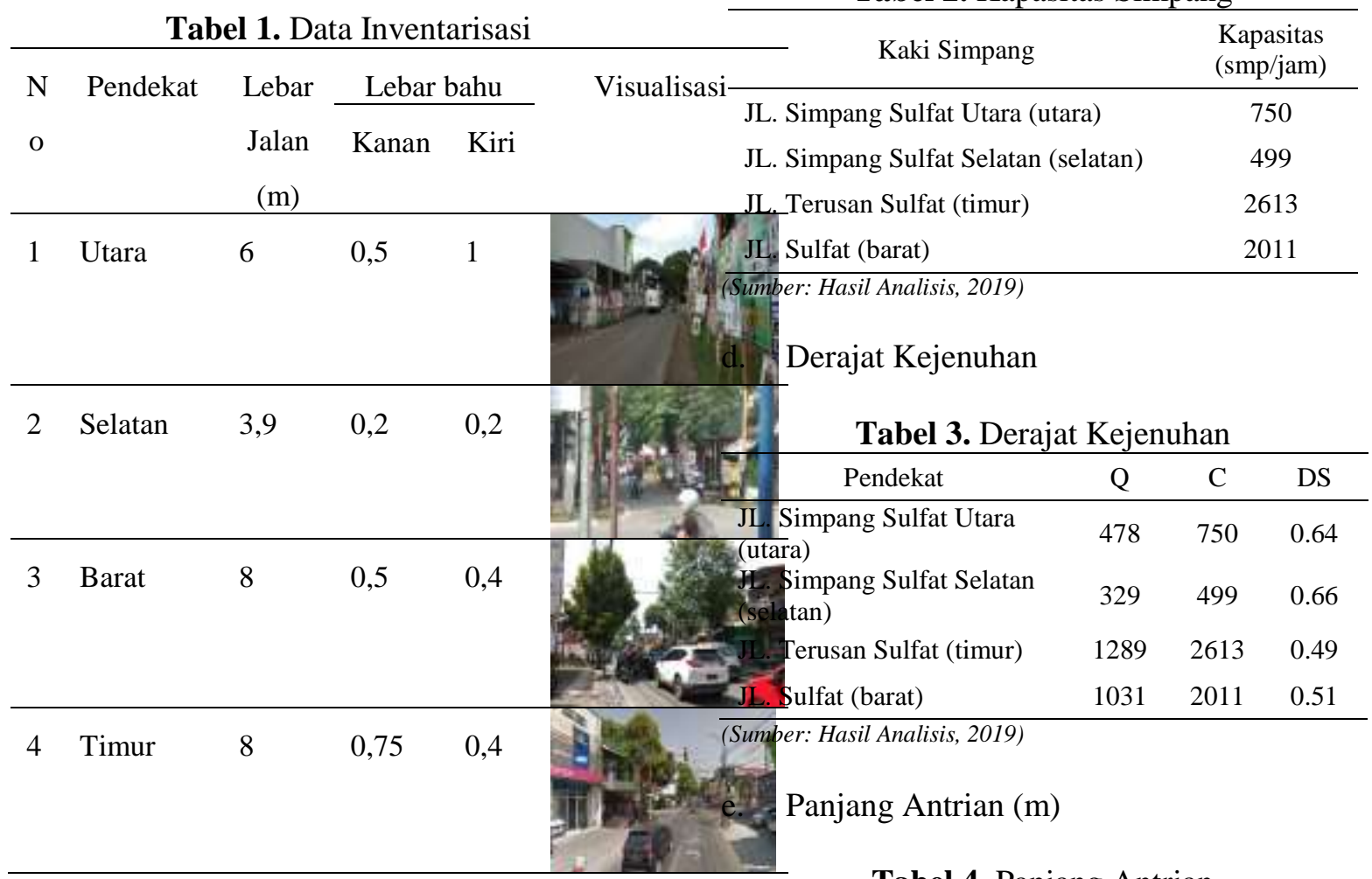

b. Volume lalu lintas

Pada Gambar 2 berikut terlihat volume jam puncak pada simpang terusan sulfat yaitu pada pukul 06.45-07.45 dengan jumlah 3.129 smp/jam.



Gambar 2. Volume Lalu Lintas

\section{c. Kapasitas}

Tabel 2. Kapasitas Simpang

Tabel 4. Panjang Antrian

\begin{tabular}{lccc}
\hline \multicolumn{1}{c}{ Pendekat } & NQmax $_{\max }$ & $\mathrm{W}_{\text {masuk }}$ & $\begin{array}{c}\text { QL } \\
(\mathrm{m})\end{array}$ \\
\hline $\begin{array}{l}\text { JL. Simpang Sulfat Utara } \\
\text { (utara) }\end{array}$ & 13,51 & 6 & 45 \\
$\begin{array}{l}\text { JL. Simpang Sulfat Selatan } \\
\text { (selatan) }\end{array}$ & 9,27 & 3.9 & 48 \\
JL. Terusan Sulfat (timur) & 36,43 & 8 & 91 \\
JL. Sulfat (barat) & 29,12 & 8 & 73 \\
\hline (Sumber: Hasil Analisis, 2019) & & &
\end{tabular}

f. Tundaan (det/smp)

Tabel 5. Tundaan Rata-Rata

\begin{tabular}{lccc}
\hline \multicolumn{1}{c}{ Pendekat } & $\begin{array}{c}\text { DT } \\
\text { (det/smp) }\end{array}$ & $\begin{array}{c}\text { DG } \\
\text { (det/smp) }\end{array}$ & $\begin{array}{c}\text { D } \\
\text { (det/smp) }\end{array}$ \\
\hline $\begin{array}{l}\text { JL. Simpang Sulfat } \\
\text { (utara) }\end{array}$ & 51.1 & 4 & 55.1 \\
$\begin{array}{l}\text { JL. Simpang Sulfat } \\
\begin{array}{l}\text { Selatan (selatan) } \\
\text { JL. Terusan Sulfat }\end{array}\end{array}$ & 51.6 & 3.9 & 55.5 \\
$\begin{array}{l}\text { (timur) } \\
\text { JL. Sulfat (barat) }\end{array}$ & 49.7 & 3.8 & 53.5 \\
\hline (Sumber: Hasil Analisis, 2019) & 49.6 & 3.8 & 53.4 \\
\hline
\end{tabular}


Berdasarkan perhitungan nilai tundaan rata-rata tiap pendekat, maka didapat nilai tingkat pelayanan simpang Terusan Sulfat berdasarkan PM 96 tahun 2015 adalah E [8].

Di mana jalan pada simpang ini merupakan jalan arteri sekunder, tingkat pelayanan sekurang-kurangnya adalah $\mathrm{C}$. Dengan kondisi ini simpang dalam keadaan yang kurang baik dan diperlukan penanganan pada simpang Terusan Sulfat tersebut.

Setelah di ketahui hasil perhitungan berdasarkan MKJI, selanjutnya di mikrosimulasikan menggunakan VISSIM. Sebelum di simulasikan perlu dilakukan validasi terhadap kondisi eksisting pada VISSIM sehingga hasil simulasi dapat menggambarkan kondisi eksisting. Validasi pada simulasi menggunakan beberapa parameter yaitu:

a. Volume lalu lintas

Uji validasi terhadap volume lalu lintas menggunakan rumus chi-square GEH seperti di bawah.

$$
G E H=\sqrt{ } \frac{(q \text { simulasi }-q \text { observasi } i) 2}{0.5 x(q \text { simulasi }+q \text { observas } i)}
$$

Dengan menggunakan rumus di atas maka diketahui hasil validasi GEH seperti pada Tabel 6.

Tabel 6. Uji GEH

\begin{tabular}{clcccc}
\hline \multirow{2}{*}{ Lengan Simpang } & Arah & \multicolumn{2}{c}{$\begin{array}{c}\text { Volume } \\
\text { Kendaraan } \\
\text { (kend/jam) }\end{array}$} & GEH \\
\cline { 2 - 6 } & & observasi & Vissim & Hasil keterangan \\
\hline JL. Simpang Sulfat & Kiri & 333 & 307 & 1.5 & DITERIMA \\
Utara (utara) & Lurus & 286 & 289 & 0.2 & DITERIMA \\
& Kanan & 282 & 288 & 0.4 & DITERIMA \\
JL. Simpang Sulfat & Kiri & 155 & 123 & 2.7 & DITERIMA \\
Selatan (selatan) & Lurus & 398 & 344 & 2.8 & DITERIMA \\
& Kanan & 203 & 164 & 2.9 & DITERIMA \\
JL. Terusan Sulfat & Kiri & 268 & 254 & 0.9 & DITERIMA \\
& Lurus & 1,672 & 1680 & 0.2 & DITERIMA \\
& Kanan & 698 & 672 & 1 & DITERIMA \\
& Kiri & 596 & 600 & 0.2 & DITERIMA \\
JL. Sulfat (barat) & Lurus & 1,256 & 1272 & 0.5 & DITERIMA \\
& Kanan & 145 & 136 & 0.8 & DITERIMA \\
\hline \multicolumn{5}{c}{ Rata-rata } \\
\hline Sumber.
\end{tabular}

Berdasarkan Tabel 6, hasil dari uji GEH rata-rata di bawah dari 5 sehingga bisa simulasi dapat diterima.

b. Kecepatan kendaraan

Uji validasi terhadap kecepatan menggunakan rumus MAPE yang membandingkan hasil observasi dengan output data dari VISSIM.
Tabel 7. Uji MAPE

\begin{tabular}{lccc}
\hline \multirow{2}{*}{ Lengan Simpang } & \multicolumn{2}{c}{ Kecepatan $(\mathrm{km} / \mathrm{jam})$} & $\begin{array}{c}\text { Uji } \\
\text { MAPE }\end{array}$ \\
\cline { 2 - 4 } & Vissim & Observasi & Hasil \\
\hline JL. Simpang & 29.82 & 28.5 & $5 \%$ \\
Sulfat Utara & & & \\
JL. Simpang & 29.18 & 28.4 & $3 \%$ \\
Sulfat Selatan & 27.81 & 29.5 & $6 \%$ \\
JL. Terusan Sulfat & 27.9 & 28.7 & $3 \%$ \\
JL. Sulfat & &
\end{tabular}

Berdasarkan Tabel 7, hasil dari uji MAPE tertinggi adalah $6 \%$ yang berarti $94 \%$ simulasi dapat menggambarkan kondisi eksisting.

c. Panjang antrian

Uji validasi terhadap panjang antrian menggunakan uji paired sample t-test karena menggunakan nilai rata-rata pada panjang antrian, uji ini dilakukan menggunakan SPSS dan diketahui hasilnya seperti pada Tabel 8.

Tabel 8. Uji Paired Sample t-test

\begin{tabular}{|c|c|c|c|}
\hline \multirow{2}{*}{ Lengan Simpang } & \multicolumn{2}{|c|}{ Panjang Antrian } & \multirow{2}{*}{$\begin{array}{c}\text { Paired } \\
\text { Sample T } \\
\text { test }\end{array}$} \\
\hline & Vissim & Observasi & \\
\hline JL. Simpang Sulfat Utara & 30.7 & 35 & \multirow{4}{*}{0.002} \\
\hline JL. Simpang Sulfat Selatan & 99.3 & 88 & \\
\hline JL. Terusan Sulfat & 25.1 & 32 & \\
\hline JL. Sulfat & 27.3 & 30 & \\
\hline
\end{tabular}

Berdasarkan Tabel 8 hasil uji kurang dari 0,05 yang berarti panjang antrian pada simulasi dapat merepresentasikan panjang antrian pada kondisi eksisting.

Setelah dilakukan validasi terhadap VISSIM diketahui hasil dari nilai tundaan seperti pada Tabel 9.

Tabel 9. Output Data VISSIM

\begin{tabular}{lccc}
\hline \multicolumn{1}{c}{ Pendekat } & $\begin{array}{c}\text { Tundaan } \\
\text { (detik/smp) }\end{array}$ & $\begin{array}{c}\text { Tundaan simpang } \\
\text { (detik/smp) }\end{array}$ & $\begin{array}{c}\text { Tingkat } \\
\text { Pelayanan }\end{array}$ \\
\hline JL. Simpang Sulfat Utara (utara) & 48.1 & & \\
JL. Simpang Sulfat Selatan & 158.8 & 63.1 & $\mathrm{~F}$ \\
(selatan) & 19.9 & & \\
JL. Terusan Sulfat (timur) & 25.8 & & \\
JL. Sulfat (barat) & & \\
\hline (Sumber: Hasil Analisis, 2019)
\end{tabular}

Berdasarkan nilai tundaan rata-rata tiap pendekat, maka didapat nilai tingkat pelayanan simpang Terusan Sulfat berdasarkan PM 96 tahun 2015 adalah F [8]. 


\subsection{Konflik Lalu Lintas}

Setelah dilakukan survei menggunakan video, selanjutnya dilakukan pengamatan video oleh dua orang untuk menghasilkan data yang reliabel. Untuk menguatkan bahwa rekapitulasi data konflik yang terjadi memang dapat digunakan dalam penelitian maka sebelum konflik yang terjadi dianalisa dengan menggunakan SSAM, perlu dilakukan uji reliabilitas. Uji reliabilitas dilakukan dengan Chi-Square Tests menggunakan software SPSS. Uji Chi-Square digunakan untuk menguji perbedaan apakah dua sampel (dengan data nominal) tidak ada hubungan (independen) atau saling berhubungan. Hasil dari pengamatan ditunjukan pada Tabel 10.

Tabel 10. Konflik Pengamat

\begin{tabular}{|c|c|c|c|}
\hline $\begin{array}{c}\text { Jenis } \\
\text { konflik }\end{array}$ & Pengamat 1 & Pengamat 2 & Total \\
\hline Crossing & 1687 & 1797 & 3484 \\
\hline Lane change & 703 & 589 & 1292 \\
\hline Total & 2390 & 2386 & 4776 \\
\hline
\end{tabular}

H0:Tidak ada persamaan pengamatan konflik lalu lintas

Ha:Terdapat persamaan pengamatan konflik lalu lintas

Berdasarkan hasil analisis menggunakan software SPSS diperoleh hasil nilai Pearson Chi-Square signifikan dengan probabilitas sebesar 0,000 $(\mathrm{p}<0,05)$. Dengan hasil tersebut, maka dapat disimpulkan bahwa terdapat persamaan pengamatan konflik antara pengamat 1 dan pengamat 2 .

Setelah diketahui hasil dari uji chisquare antara pengamat 1 dan 2 , maka dipilih dalah satu untuk di uji dengan output data konflik dari software SSAM seperti pada Tabel 11.

Tabel 11. Konflik Pengamat dan SSAM

\begin{tabular}{lccc}
\hline \multicolumn{1}{c}{ Jenis konflik } & Pengamat & SSAM & Total \\
\hline Crossing & 1687 & 2035 & 3722 \\
Lane change & 703 & 747 & 1450 \\
\hline \multicolumn{1}{c}{ Total } & 2390 & 2782 & 5172 \\
\hline (Sumber: Hasil Analisis, 2019) & &
\end{tabular}

Berdasarkan hasil analisis menggunakan software SPSS diperoleh hasil nilai Pearson Chi-Square signifikan dengan probabilitas sebesar 0,041 $(\mathrm{p}<0,05)$. Dengan hasil tersebut, maka dapat disimpulkan bahwa terdapat persamaan pengamatan konflik antara pengamat dan SSAM. Hal ini bisa terjadi karena pengamat mengamati konflik lalu lintas pada mulut simpang saja dan SSAM dapat di filter berdasarkan kebutuhan data yaitu pada mulut simpang saja. Berikut merupakan gambar persebaran dari konflik crossing (merah) dan lane change (kuning).

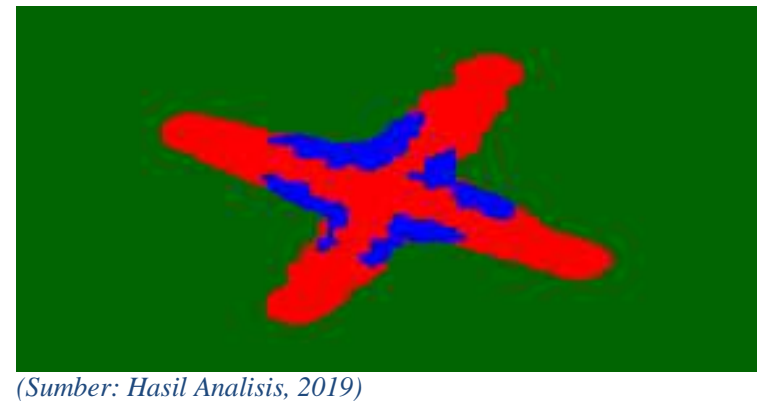

Gambar 3. Persebaran Jenis Konflik

\subsection{Alternatif Solusi Penanganan}

Berdasarkan hasil pada kondisi eksisting simpang Terusan Sulfat, di ketahui nilai tundaan dan jumlah konflik yang terjadi, maka dari itu perlunya penurunan jumlah konflik dalam upaya peningkatan keselamatan di simpang Terusan Sulfat perlu dilakukan dengan beberapa usulan sebagai berikut:

\section{a. Pengaturan simpang 2 fase dengan start awal belok kanan}

Diagram fase untuk pengaturan simpang dengan 2 fase.

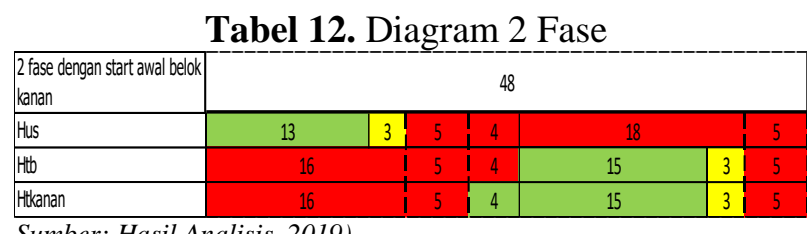

Sumber: Hasil Analisis, 2019)

Dengan menggunakan pengaturan fase di atas, maka hasil simulasi dapat di ketahui menggunakan VISSIM dengan hasil nilai tundaan dan jumlah konflik yang terjadi menggunakan output data dari SSAM.

\section{b. Pengaturan simpang 3 fase}

Diagram fase untuk pengaturan simpang dengan 3 fase. 
Tabel 13. Diagram 3 Fase

\begin{tabular}{|c|c|c|c|c|c|}
\hline BFase & \multicolumn{5}{|c|}{87} \\
\hline His & 19 & 26 & 5 & 24 & \\
\hline th. & 12 & 23 & 5 & 24 & \\
\hline tho & 12 & 26 & 5 & 21 & 3 \\
\hline
\end{tabular}

Dengan menggunakan pengaturan fase di atas, maka hasil simulasi dapat di ketahui menggunakan VISSIM dengan hasil nilai tundaan dan jumlah konflik yang terjadi menggunakan output data dari SSAM.

Hasil yang diperoleh dari kedua alternatif solusi penanganan seperti pada Tabel 14.

Tabel 14. Hasil Alternatif Solusi Penanganan

\begin{tabular}{llccc}
\hline Usulan Alternatif & $\begin{array}{c}\text { Eksistin } \\
\mathrm{g} \\
\text { (2 Fase) }\end{array}$ & $\begin{array}{c}\text { 2 fase } \\
\text { dengan start } \\
\text { awal belok } \\
\text { kanan }\end{array}$ & 3 Fase \\
\hline Vissim (tundaan) & 63.1 & 112.5 & 132.8 \\
\hline \multirow{2}{*}{ SSAM } & $\begin{array}{l}\text { Crossing } \\
\text { Lane } \\
\text { Change }\end{array}$ & 2035 & 1580 & 1082 \\
\cline { 2 - 5 } & 747 & 817 & 471 \\
\hline Thumber: Hasil Analisis, 2019) & & &
\end{tabular}

Berdasarkan hasil alternatif solusi penanganan di atas nilai keselamatan dan kelancaran saling bertolak belakang, maka perlu adanya pelebaran geometri simpang untuk menurunkan nilai tundaan. Berdasarkan kondisi eksisting yang ada, usulan pelebaran mulut simpang seperti Tabel 15.

Tabel 15. Pelebaran Mulut Simpang

\begin{tabular}{lcc}
\hline \multicolumn{1}{c}{ Pendekat } & $\begin{array}{c}\text { Lebar Awal } \\
(\mathrm{m})\end{array}$ & $\begin{array}{c}\text { Lebar } \\
\text { Usulan }(\mathrm{m})\end{array}$ \\
\hline $\begin{array}{l}\text { Jl. Simpang Sulfat } \\
\text { Utara }\end{array}$ & 6 & 6 \\
$\begin{array}{l}\text { Jl. Simpang Sulfat } \\
\text { Selatan }\end{array}$ & 3,9 & 6 \\
Jl. Terusan Sulfat & 8 & 12 \\
Jl. Sulfat & 8 & 12 \\
\hline Sumber: Hasil Analisis, 2019) & &
\end{tabular}

(Sumber: Hasil Analisis, 2019)

Berdasarkan hasil dari perhitungan dengan menggunakan alternatif solusi penanganan terbaik pada peningkatan keselamatan dengan menggunakan pengaturan simpang yaitu dengan menggunakan 3 fase, serta untuk menurunkan nilai tundaan pada simpang dengan pelebaran geometri jalan mengalami penurunan baik dari nilai tundaan dan jumlah konflik yang masing-masing sebesar $26 \%$ dan $2 \%$ dari kondisi eksisting. Dengan mengetahui prediksi peningkatan jumlah kendaraan pada tahun selanjutnya menggunakan metode perhitungan growth factor dengan rumus :

$$
\mathrm{Pn}=\mathrm{Po}_{0}+(1+\mathrm{i})^{\mathrm{N}}
$$

Dengan :

Pn = Jumlah volume lalu lintas pada akhir tahun ke-n

Po = Jumlah volume lalu lintas mula-mula

I $=$ Tingkat pertumbuhan (rate of interest)

$\mathrm{N} \quad=$ Banyak waktu(dalam tahun)

Didapatkan hasil seperti pada Tabel 18.

Tabel 16. Nilai Tundaan

\begin{tabular}{lccc}
\hline \multicolumn{1}{c}{ Pendekat } & $\begin{array}{c}\text { Tundaan } \\
\text { (detik/smp) }\end{array}$ & $\begin{array}{c}\text { Tundaan } \\
\text { simpang } \\
\text { (detik/smp) }\end{array}$ & $\begin{array}{c}\text { Tingkat } \\
\text { Pelayanan }\end{array}$ \\
\hline $\begin{array}{l}\text { JL. Simpang Sulfat } \\
\text { Utara (utara) }\end{array}$ & 32 & & \\
$\begin{array}{l}\text { JL. Simpang Sulfat } \\
\text { Selatan (selatan) }\end{array}$ & 30 & 47 & $\mathrm{E}$ \\
$\begin{array}{l}\text { JL. Terusan Sulfat } \\
\text { (timur) }\end{array}$ & 65 & & \\
JL. Sulfat (barat) & 59 & & \\
\hline $\begin{array}{l}\text { (Sumber: Hasil Analisis, 2019) } \\
\end{array}$ &
\end{tabular}

Tabel 17. Jumlah Konflik

\begin{tabular}{|c|c|}
\hline Jenis konflik & Jumlah Konflik \\
\hline Crossing & 1827 \\
\hline Lane change & 887 \\
\hline Total & 2714 \\
\hline
\end{tabular}

(Sumber: Hasil Analisis, 2019)

Tabel 18. Growth Factor Jumlah Kendaraan di Kota Malang

\begin{tabular}{ccc}
\hline \multicolumn{3}{c}{ Data Jumlah Kendaraan } \\
\hline No & Tahun & Jumlah Kendaraan \\
\hline 1 & 2015 & 547615 \\
2 & 2016 & 567719 \\
3 & 2017 & 592772 \\
4 & 2018 & 620085 \\
5 & 2019 & 649973 \\
6 & 2020 & 682811 \\
7 & 2021 & 719052 \\
8 & 2022 & 759241 \\
9 & 2023 & 804049 \\
10 & 2024 & 854302 \\
11 & 2025 & 911032 \\
\hline (Sumber: Hasil Analisis, 2019)
\end{tabular}


Tabel 19. Peningkatan Jumlah Kendaraan di Kota Malang

\begin{tabular}{cc}
\hline Tahun & Persentase \\
\hline 2020 & $105 \%$ \\
2025 & $140 \%$ \\
\hline
\end{tabular}

Sumber: Hasil Analisis, 2019)

Berdasarkan hasil perhitungan growth factor jumlah kendaraan di Kota Malang dapat di ketahui pada tahun 2020 dan 2025 di perkirakan sebesar 5\% dan 40\%, selanjutnya untuk mengetahui jumlah konflik dan nilai tundaan yang terjadi pada simpang Terusan Sulfat dikalikan pada kondisi volume eksisting sehingga di dapat hasil pada perhitungan menggunakan VISSIM dan SSAM seperti pada Tabel 20.

Tabel 20. Perbandingan Growt Factor

\begin{tabular}{ccccc}
\hline \multirow{2}{*}{ Growth Factor } & \multicolumn{3}{c}{ Eksisting (2 Fase) } \\
\cline { 2 - 5 } & $\begin{array}{c}\text { Tahun } \\
2019\end{array}$ & $\begin{array}{c}\text { Tahun } \\
2020\end{array}$ & $\begin{array}{c}\text { Tahun } \\
2025\end{array}$ \\
\hline Vissim (tundaan) & 63 & 97 & 108 \\
\hline \multirow{2}{*}{ SSAM } & Crossing & 2035 & 2477 & 2564 \\
& $\begin{array}{l}\text { Lane } \\
\text { Change }\end{array}$ & 747 & 1691 & 1620 \\
\cline { 2 - 5 } & Total & 2782 & 4168 & 4184 \\
\hline (Sumber: Hasil Analisis, 2019) & & &
\end{tabular}

Berdasarkan hasil perhitungan dari growth factor pada kondisi eksisting tahun 2020 dan tahun 2025 selalu mengalami peningkatan karena volume kendaraan meningkat sehingga diperlukan adanya peningkatan kapasitas simpang berupa pelebaran mulut simpang dan pengaturan fase yang sesuai untuk mengurangi adanya jumlah konflik dan nilai tundaan yang meningkat.

\section{KESIMPULAN DAN SARAN}

Berdasarkan analisis yang telah dilakukan pada bab sebelumnya maka dapat disimpulkan bahwa :

1. Kinerja simpang Terusan Sulfat pada jam puncak tertinggi yaitu pada pukul 06.4507.45 memiliki nilai tundaan sebesar 54,4 detik dan memiliki tingkat pelayanan kategori E berdasarkan PM 96 tahun 2015 yang artinya di bawah dari ketentuan yaitu sekurang-kurangnya $\mathrm{C}$ karena pada lokasi termasuk fungsi jalan arteri sekunder.

2. Konflik yang terjadi di simpang Terusan Sulfat selama jam puncak tertinggi menurut SSAM berjumlah 2782 konflik yang terdiri dari 2035 berupa konflik crossing dan 747 berupa konflik lane change.

3. Alternatif solusi yang di gunakan ialah perubahan waktu siklus dan fase pada simpang Terusan Sulfat yang terdiri dari 2 fase dengan start awal belok kanan dan 3 fase dengan masing-masing mengalami penurunan konflik sebesar $14 \%$ dan $44 \%$, akan tetapi memiliki nilai tundaan yang meningkat sebesar $78 \%$ dan $110 \%$ sehingga perlu adanya manajemen kapasitas simpang berupa pelebaran mulut simpang, hal ini di dukung dengan adanya prediksi pertumbuhan jumlah kendaraan di kota Malang pada tahun 2020 dan 2025 meningkat sebesar 5\% dan $40 \%$ yang mengakibatkan nilai tundaan meningkat sebesar $54 \%$ dan $71 \%$ dan jumlah konflik meningkat $50 \%$. Berdasarkan kondisi eksisting yang tersedia pelebaran mulut simpang di lakukan pada pendekat Jalan Sulfat, Jalan Terusan Sulfat dan Jalan Simpang Sulfat Selatan dengan pelebaran sebesar 4 meter, 4 meter dan 2,1 meter dengan hasil kinerja menunjukan nilai tundaan dengan pelebaran mulut simpang serta penurunan jumlah konflik terbesar yaitu 3 fase memiliki nilai tundaan 47 detik dan jumlah konflik berdasarkan SSAM 2714 konflik ini menunjukan adanya penurunan sebesar $26 \%$ dan $2 \%$ dari kondisi eksisting simpang Terusan Sulfat.

Berdasarkan hasil kesimpulan tersebut maka untuk mengatasi permasalahan pada simpang Terusan Sulfat, penulis menyarankan sebagai berikut :

1. Untuk meningkatkan keselamatan pada simpang Terusan Sulfat di perlukan adanya perubahan fase pengaturan simpang kondisi 2 fase menjadi 3 fase untuk menurunkan jumlah konflik yang terjadi pada simpang Terusan Sulfat.

2. Untuk meningkatkan nilai tundaan pada simpang Terusan Sulfat di perlukan adanya manajemen kapasitas simpang berupa pelebaran mulut simpang sehingga pada kondisi jam puncak tertinggi tundaan rata-rata yang terjadi tidak tinggi. 
3. Untuk menyeimbangkan antara kelancaran dan keselamatan di perlukan penanganan secara bersamaan antara pengaturan simpang dan perubahan geometri jalan sehingga dapat meningkatkan kinerja serta keselamatan pada simpang.

\section{UCAPAN TERIMA KASIH}

Terima kasih kepada dinas perhubungan kota malang yang telah membantu dalam pengambilan data serta instansi terkait lainnya dalam memudahkan penulis melakukan penelitian dengan sebaik-baiknya.

\section{DAFTAR PUSTAKA}

[1] Direktorat Jenderal Bina Marga.,Manual Kapasitas Jalan Indonesia (MKJI)1997. Jakarta : Departeman Pekerjaan Umum, 1997

[2] Direktorat Jenderal Bina Marga, Panduan Teknis 1 Rekayasa Keselamatan Jalan, Serial Rekayasa Keselamatan Jalan, Jakarta, 2012

[3] Candra Winarto, Pipit., Analisis Simpang Bersinyal Menggunakan Software VISSIM.Skripsi , tidak diterbitkan Yogyakarta:Universitas Muhammadiyah Yogyakarta, 2016

[4] Al-Rajie,Haitham. Investigation of using microscopic traffic simulation tools to predict traffic conflicts between right turning vehicles and through cyclists at signalized intersections. Tesis. Tidak Diterbitkan. Ottawa: Carleton Institute of Civil and Environmental Engineering, 2015

[5] Christy, C. Jothin dan B. Kent Lall. Dasar-Dasar Rekayasa Lalu Transportasi Jakarta, 2005

[6] Planung Transport Verkehr AG., VISSIM 10.0 User Manual. Planung Transport Verkehr AG PTV, Karslruhe German, 2016

[7] Federal Highway Administration (FHWA). Surrogate Safety Assessment Model and Validation : Final report. US: Departemen of Transportation Washington D.C, .2008

[8] Menteri Perhubungan, Peraturan Menteri Perhubungan Nomor : PM 96 Tahun 2015 tentang Pedoman Pelaksanaan Kegiatan Manajemen dan Rekayasa Lalu Lintas. Menteri Perhubungan. Jakarta, 2015

[9] Planung Transport Verkehr AG., VISSIM 10.0 User Manual. Planung Transport Verkehr AG PTV, Karslruhe German, 2016 